\title{
Double trouble: methanol outbreak in the wake of the COVID-19 pandemic in Iran-a cross-sectional assessment
}

\author{
Hossein Hassanian-Moghaddam ${ }^{1,2^{*}}$, Nasim Zamani ${ }^{1,2}$, Ali-Asghar Kolahi ${ }^{1}$, Rebecca McDonald ${ }^{3}$ and \\ Knut Erik Hovda ${ }^{4}$
}

Keywords: Alcohol, Ethanol, Poisoning, Mortality, Coronavirus

Iran has been the epicenter of COVID-19 in the Middle East, with a total of 120,198 infected cases and 8556 deaths as of June 10 [1]. The pandemic has been complicated by the co-occurrence of a large methanol outbreak in Iran, seemingly triggered by false claims that consumption of disinfectants and alcohols could prevent and treat COVID-19 infection. According to local news, the ensuing rise in ethanol demand made bootleggers decolorate industrial alcohols containing pyridine (to deter from consumption) using bleach, before selling them as regular ethanol to Iranians.

In this research letter, we describe the scale of the Iranian methanol outbreak, based on hospitalization and mortality data collated from databases of the Iranian Ministry of Health $(\mathrm{MOH})$ and Legal Medicine Organization (LMO) for the period of February 23 (first documented COVID-19 case in Iran) until May 2, 2020. MOH records indicate 5876 hospitalizations for methanol poisoning, occurring in geographical clusters, with just three (Tehran, Fars, Khuzestan) out of the total 31 Iranian provinces accounting for the majority $(52.2 \% ; n=3068)$ of cases (see Table 1). In terms of mortality, $\mathrm{MOH}$ reported that 534 patients with methanol poisoning were confirmed dead in the hospital setting, equivalent to an estimated

\footnotetext{
* Correspondence: hassanian@sbmu.ac.ir; hasanian2000@yahoo.com ${ }^{1}$ Social Determinants of Health Research Center, Shahid Beheshti University of Medical Sciences, Tehran, Iran

${ }^{2}$ Department of Clinical Toxicology, Loghman Hakim Hospital, School of Medicine, Shahid Beheshti University of Medical Sciences, South Karegar Street, Tehran, Iran

Full list of author information is available at the end of the article
}

case fatality rate of approximately $9 \%(534 / 5876)$. LMO registered 800 deaths from methanol poisoning during the same period (see Table 1 and Fig. 1), comprising both in-hospital and community-based fatalities. This $33 \%$ discrepancy in deaths between $\mathrm{MOH}$ and $\mathrm{LMO}$ data (i.e., $(800-534) / 800 \times 100)$ may have several explanations. For instance, LMO data also includes out-of-hospital deaths and is likely more accurate. Moreover, a hospitalbased diagnosis of methanol poisoning is difficult and complicated by the lack of diagnostic equipment or physician knowledge. Therefore, methanol poisoning may go undetected in hospitals, and accurate diagnosis is-best case scenario-only assigned during a post-mortem examination, which then enters LMO statistics. In the absence of formate analyses, late presenters can become false negatives.

Despite these inconsistencies, the number of Iranian poisoning cases (5876 hospitalizations from late February until early May), $\backslash$ is already five times higher than the second-largest methanol outbreak in history, which was recorded in Libya in March 2013 and affected 1066 patients [2].

From our data, it is unclear how many Iranians drank adulterated alcohol for recreational purposes or as gastrointestinal "disinfectant" to prevent-or treatCOVID-19 infection. With no end to the COVID-19 pandemic in sight, it is thus paramount to educate the general public that alcohol does not protect against COVID-19, as already initiated by the WHO [3]. The United Nations rightly recognizes the international spread of "fake news" related to COVID-19 as a threat 
Table 1 Methanol poisoning cases and fatalities in Iran (23 February to 2 May 2020)

\begin{tabular}{|c|c|c|c|}
\hline \multirow[t]{2}{*}{ Province } & \multirow{2}{*}{$\begin{array}{l}\text { Poisoning cases: } \\
\text { hospital admissions } \\
\text { (source: } \mathrm{MOH} \text { ) }\end{array}$} & \multicolumn{2}{|l|}{ Methanol deaths* } \\
\hline & & In hospital (source: $\mathrm{MOH}$ ) & Total registered (source: LMO) \\
\hline Tehran & 1177 & 87 & 205 \\
\hline Khuzestan & 1079 & 93 & 88 \\
\hline Fars & 812 & 99 & 139 \\
\hline Razavi Khorasan & 581 & 67 & 78 \\
\hline East Azerbaijan & 483 & 50 & 75 \\
\hline Alborz & 248 & 43 & 52 \\
\hline Ardebil & 223 & 22 & 31 \\
\hline Isfahan & 207 & 6 & 19 \\
\hline Kerman & 139 & 0 & 2 \\
\hline Kermanshah & 132 & 2 & 2 \\
\hline Mazandaran & 100 & 10 & 28 \\
\hline Yazd & 96 & 12 & 10 \\
\hline Markazi & 87 & 4 & 4 \\
\hline Kurdestan & 79 & 0 & 9 \\
\hline The other provinces & 433 & 39 & 58 \\
\hline Total & 5876 & 534 & 800 \\
\hline
\end{tabular}

*Brain-dead cases considered dead

MOH Ministry of Health, LMO Legal Medicine Organization (data is available through https://bit.ly/2WUBfZo)

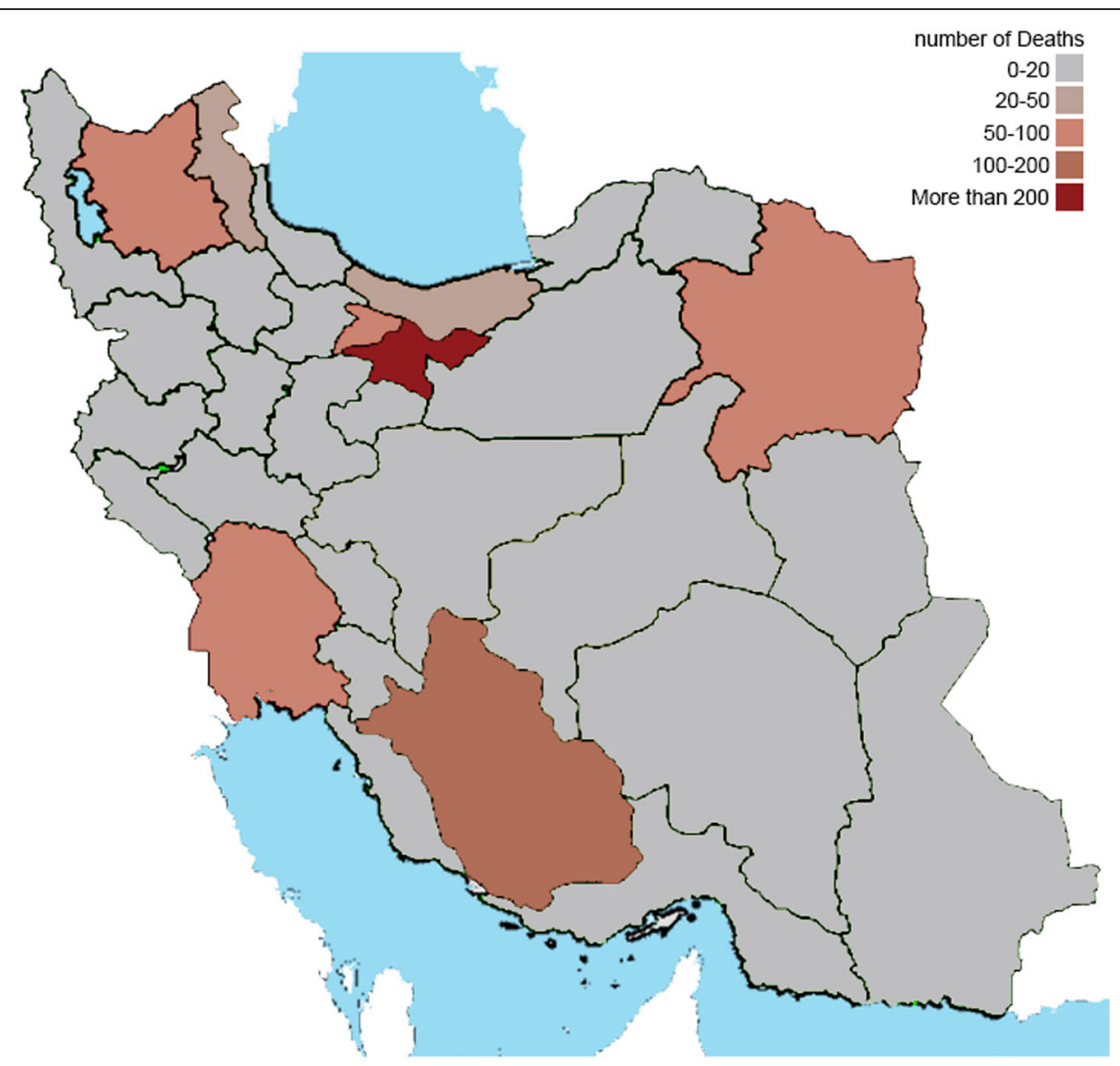

Fig. 1 Mortality by province based on LMO data 
to human lives [4], as health care systems have to contend with medical misinformation of the general public.

In methanol poisoning, the efficacy of treatment is markedly reduced in delayed presentations. With 534 methanol deaths registered by $\mathrm{MOH}$ and 800 deaths by LMO, alongside 5876 hospitalizations, we report an estimated mortality rate in the range of $9-14 \%$. However, this figure is preliminary and should be interpreted with great caution, until LMO and $\mathrm{MOH}$ release their final data. Additionally, in many more non-fatal methanol poisoning cases, adults and children are now visionimpaired or blind from this toxic alcohol.

During situations like pandemics, healthcare institutions may seem dangerous settings, which could pose a risk of viral infection. It is possible that fear of COVID-19 kept methanol poisoning victims from seeking and obtaining timely care. This highlights the importance of early identification and initiation of treatment, which can be supplemented by "active case finding" by treating physicians and public health agencies [5]. Public health messaging and strategic planning are crucial to prevent future methanol outbreaks [6].

\section{Acknowledgements}

We want to acknowledge the novel initiative by Medécins sans Frontières (MSF/Doctors without Borders) which looks at mechanisms to improve the survival of methanol poisoning victims globally. Methanol poisoning is an under-recognized issue, especially in low- and middle-income countries. For more information on the work of MSF regarding methanol poisoning, please visit https://msf.no/mpi.

\section{Authors' contributions}

HHM helped in the conception and design of the study. AAK, HHM, and NZ contributed to the data collection. NZ helped in writing the first draft. RM and $\mathrm{KEH}$ composed the final draft. All authors contributed to the final approval of the version to be submitted. All authors read and approved the final manuscript.

\section{Funding}

Shahid Beheshti University of Medical Sciences

\section{Availability of data and materials}

All the data is presented in the text.

\section{Ethics approval and consent to participate}

This study is a preliminary report and was approved by the ethics committee of Shahid Beheshti University of Medical Sciences

(IR.SBMU.RETECH.REC.1398.872).

\section{Consent for publication}

Not applicable

\section{Competing interests}

The authors declare that they have no competing interests.

\section{Author details}

'Social Determinants of Health Research Center, Shahid Beheshti University of Medical Sciences, Tehran, Iran. ${ }^{2}$ Department of Clinical Toxicology, Loghman Hakim Hospital, School of Medicine, Shahid Beheshti University of Medical Sciences, South Karegar Street, Tehran, Iran. ${ }^{3}$ National Addiction Centre, Institute of Psychiatry, Psychology and Neuroscience, King's College London, London, UK. ${ }^{4}$ The Norwegian CBRNE Centre of Medicine, Department of Acute Medicine, Oslo University Hospital, Oslo, Norway.
Received: 12 June 2020 Accepted: 1 July 2020

Published online: 09 July 2020

References

1. Iran report on Coronavirus cases: 177,938; deaths 8,556. Available through: https://www.worldometers.info/coronavirus/country/iran/. Accessed 10 June 2020

2. Rostrup M, Edwards JK, Abukalish M, Ezzabi M, Some D, et al. Correction: the methanol poisoning outbreaks in Libya 2013 and Kenya 2014. PLoS One. 2016;11(6):e0157256.

3. Alcohol and COVID-19: what you need to know. Available through: http:// www.euro.who.int/en/health-topics/health-emergencies/coronavirus-covid-1 9/technical-guidance/2020/alcohol-and-covid-19-what-you-need-to-know,-7april-2020. Accessed 11 June 2020.

4. During this coronavirus pandemic, 'fake news' is putting lives at risk: UNESCO. Available through: https://news.un.org/en/story/2020/04/1061592. Accessed 18 May 2020.

5. Hassanian-Moghaddam H, Nikfarjam A, Mirafzal A, et al. Methanol mass poisoning in Iran: role of case finding in outbreak management. J Public Health. 2015:37:354-9.

6. Hassanian-Moghaddam H, Zamani N, Roberts DM, et al. Consensus statements on the approach to patients in a methanol poisoning outbreak. Clin Toxicol. 2019;57(12):1129-36.

\section{Publisher's Note}

Springer Nature remains neutral with regard to jurisdictional claims in published maps and institutional affiliations.
Ready to submit your research? Choose BMC and benefit from:
- fast, convenient online submission
- thorough peer review by experienced researchers in your field
- rapid publication on acceptance
- support for research data, including large and complex data types
- gold Open Access which fosters wider collaboration and increased citations
- maximum visibility for your research: over $100 \mathrm{M}$ website views per year
At BMC, research is always in progress.
Learn more biomedcentral.com/submissions 